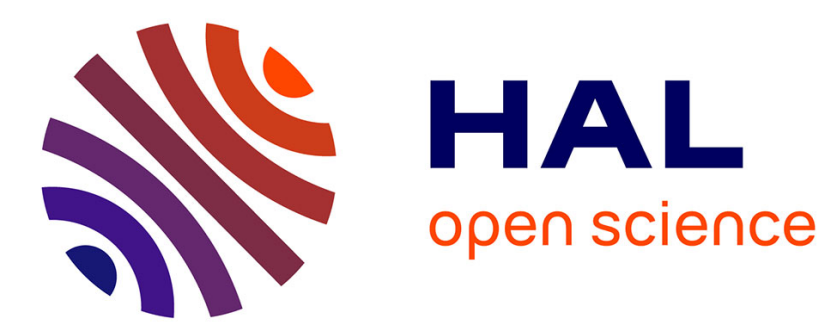

\title{
Hydrogenation of Carbonyl Derivatives Catalysed by Manganese Complexes Bearing Bidentate Pyridinyl-Phosphine Ligands
}

Duo Wei, Antoine Bruneau-Voisine, Teo Chauvin, Vincent Dorcet, Thierry Roisnel, Dmitry A. Valyaev, Noël Lugan, Jean-Baptiste Sortais

\section{To cite this version:}

Duo Wei, Antoine Bruneau-Voisine, Teo Chauvin, Vincent Dorcet, Thierry Roisnel, et al.. Hydrogenation of Carbonyl Derivatives Catalysed by Manganese Complexes Bearing Bidentate Pyridinyl-Phosphine Ligands. Advanced Synthesis and Catalysis, 2018, 360 (4), pp.676-681. 10.1002/adsc.201701115 . hal-01737372

HAL Id: hal-01737372

https://hal-univ-rennes1.archives-ouvertes.fr/hal-01737372

Submitted on 24 Apr 2018

HAL is a multi-disciplinary open access archive for the deposit and dissemination of scientific research documents, whether they are published or not. The documents may come from teaching and research institutions in France or abroad, or from public or private research centers.
L'archive ouverte pluridisciplinaire HAL, est destinée au dépôt et à la diffusion de documents scientifiques de niveau recherche, publiés ou non, émanant des établissements d'enseignement et de recherche français ou étrangers, des laboratoires publics ou privés. 
DOI: 10.1002/adsc.201((will be filled in by the editorial staff))

\title{
Hydrogenation of Carbonyl Derivatives Catalysed by Manganese Complexes Bearing Bidentate Pyridinyl- Phosphine Ligands
}

\author{
Duo Wei, ${ }^{\mathrm{a}}$ Antoine Bruneau-Voisine, ${ }^{\mathrm{a}}$ Téo Chauvin, ${ }^{\mathrm{a}}$ Vincent Dorcet, ${ }^{\mathrm{b}}$ Thierry \\ Roisnel, ${ }^{b}$ Dmitry A. Valyaev, ${ }^{c}$ Noël Lugan ${ }^{c}$ and Jean-Baptiste Sortais ${ }^{\text {a,c,d,** }}$ \\ a Institut des Sciences Chimiques de Rennes, UMR 6226 CNRS-Université de Rennes 1, Team \\ Organometallics: Materials and Catalysis, 263 av. du Général Leclerc, 35042 Rennes Cedex, France \\ b Institut des Sciences Chimiques de Rennes, UMR 6226 CNRS-Université de Rennes 1, Centre de \\ Diffractométrie X, 263 av. du Général Leclerc, 35042 Rennes Cedex, France \\ c LCC-CNRS, Université de Toulouse, INPT, UPS, 205 route de Narbonne 31077 Toulouse Cedex 4, France. \\ Email : jean-baptiste.sortais@lcc-toulouse.fr \\ d Institut Universitaire de France, 1 rue Descartes, 75231 Paris Cedex 05, France.
}

Received: ((will be filled in by the editorial staff))

Supporting information for this article is available on the WWW under

http://dx.doi.org/10.1002/adsc.201\#\#\#\#\#\#.((Please delete if not appropriate))

\begin{abstract}
Manganese(I) catalysts incorporating readily available bidentate 2-aminopyridinyl-phosphine ligands achieve a high efficiency in the hydrogenation of carbonyl compounds, significantly better than parent ones based on more elaborated and expensive tridentate 2,6(diaminopyridinyl)-diphosphine ligands. The reaction proceeds with low catalyst loading $(0.5 \mathrm{~mol} \%)$ under mild conditions $\left(50^{\circ} \mathrm{C}\right)$ with yields up to $96 \%$.
\end{abstract}

Keywords: hydrogenation; manganese; ketones; reduction; $\mathrm{P}, \mathrm{N}$-ligands

Hydrogenation with molecular dihydrogen is a clean, atom-economic and efficient reaction that has drawn a huge interest for more than a century from the Nobel Prize of Sabatier in 1912 for heterogeneous hydrogenation to the one of Noyori and Knowles in 2001 for asymmetric hydrogenation. ${ }^{[1]}$ Homogeneous hydrogenation catalysts are usually complexes based on late transition metals including ruthenium, rhodium, iridium, nickel and palladium. In the last decade, iron has emerged as a powerful sustainable alternative candidate in catalysed reduction reactions, as it is the most abundant and inexpensive transition metal. ${ }^{[2]}$ Actually, the level of the activity, and chemo- and enantioselectivity of iron catalytic systems is now comparable to the ones involving noble transition metals. ${ }^{[3]}$ Manganese, being the third most abundant transition metals after iron and titanium, has recently emerged as suitable transition metal for the design of efficient hydrogenation catalysts $^{[4]}$ starting with a seminal contribution of Beller in 2016 using the $\mathrm{Mn}^{\mathrm{I}}$ complex I featuring a tridendate bis(phosphino)amine ligand (Scheme 1). ${ }^{[5]}$
Soon after, a series of parent $\mathrm{Mn}^{\mathrm{I}}$ complexes exhibiting a variety of tridendate ligands including nitrogen and phosphorus donor fragments has been successfully applied in hydrogenation ${ }^{[6]}$ and related hydrogen borrowing reactions, ${ }^{[7]}$ selected representative examples being shown in Scheme 1.

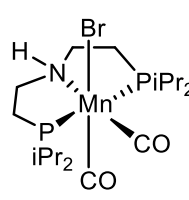

I

Beller 2016

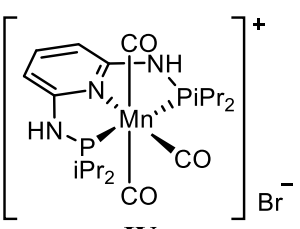
IV Sortais 2017

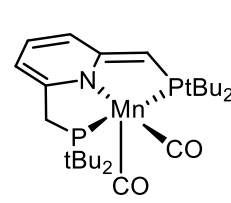

II

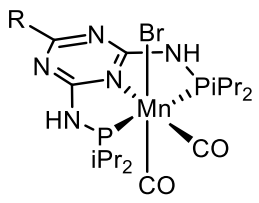

III
Milstein 2016

Kempe 2016 ( $\mathrm{R}=\mathrm{HN}-\mathrm{C}_{3} \mathrm{H}_{5}$ )

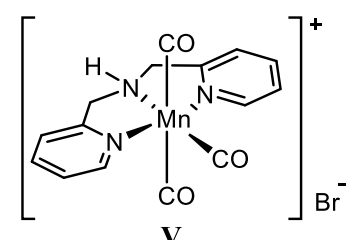

$\mathrm{V}$<smiles>O=C[N+]1(C=O)NCCP1[P+](=O)[O-]</smiles>

VI

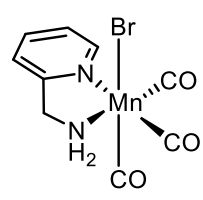

VII
Beller 2017

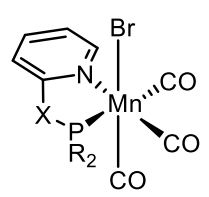

This work

Pidko-Beller 2017 (7)

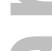
(1) 
In the course of our investigations directed toward manganese catalysed reduction reactions, ${ }^{[8]}$ we first demonstrated that the $\mathrm{PN}^{3} \mathrm{P}$ manganese complex IV bearing a 2,6-(diaminopyridinyl)-diphosphine ligand was suitable for the hydrogenation of carbonyl derivatives ${ }^{[6 c]}$ yet with moderate activity compared to $\mathrm{PN}^{5} \mathrm{P}$ analogue III developed by Kempe ${ }^{[6 \mathrm{a}]}$ and based on the 2,6-(diaminotriazinyl)-diphosphine ligand. Searching for simpler catalytic system, we found later that the manganese complex VII featuring a bidentate picolylamine ligand was significantly more active $\mathrm{e}^{[\mathrm{d}]}$ than Beller's tridendate dipicolylamine complex $\mathbf{V}^{[6 b]}$ in the case of hydrogen transfer reaction using 2propanol as the reductant. In the meantime, Pidko and Beller showed that the manganese complex VI bearing bidentate phosphinoamine ligand was as active as I for the hydrogenation of esters. ${ }^{[5 b, 9]}$ In the present contribution, we demonstrate that simple $\mathrm{Mn}^{\mathrm{I}}$ complexes bearing readily available phosphinopyridinyl PN bidentate ligands can achieve a very high efficiency in the hydrogenation of carbonyl compounds.

The ligands $\mathrm{R}_{2} \mathrm{P}-\mathrm{X}-\mathrm{Py}(\mathbf{L 1}: \mathrm{R}=i \mathrm{Pr}, \mathrm{X}=\mathrm{NH} ; \mathbf{L 2}$ : $\left.\mathrm{R}=\mathrm{Ph}, \mathrm{X}=\mathrm{NH} ; \mathbf{L 3}: \mathrm{R}=\mathrm{Ph}, \mathrm{X}=\mathrm{CH}_{2}\right)$ and $\mathrm{Ph}_{2} \mathrm{P}-$ $\mathrm{CH}_{2}-\mathrm{Qn}$ (L4) were obtained in high yield starting from the appropriate chlorophosphines $\mathrm{R}_{2} \mathrm{PCl}$ and 2aminopyridine $(\mathbf{L 1}, \mathbf{L 2}),{ }^{[10],[11]}$ 2-picoline $(\mathbf{L 3}),{ }^{[12]}$ or 2-methylquinoline (L4) ${ }^{[13]}$ respectively, according to literature procedures. The corresponding complexes $\mathrm{Mn}(\mathrm{CO})_{3} \operatorname{Br}\left(\kappa^{2} P, N\right.$-L1-L4) (1-4) (Fig. 1) were readily obtained in excellent yield (87-91\%) upon simple heating of an equimolar mixture of $\mathrm{Mn}(\mathrm{CO})_{5} \mathrm{Br}$ and the given ligand in toluene at $100{ }^{\circ} \mathrm{C}$ overnight. They were fully characterised by IR and NMR spectroscopy, high-resolution mass spectrometry and elemental analysis, and their solid-state structures were determined by single-crystal X-ray diffraction. ${ }^{[14]}$ Perspective views of the complexes are displayed on Figure 2 for complex 2, and on Figures S15, S17 and S18 for complexes 1, 3, and 4, respectively. All complexes show a typical octahedral environment for the Mn center, the L1-L4 ligands being coordinated in a $\kappa^{2} P, N$ mode and the three carbonyl ligands being in facial position.
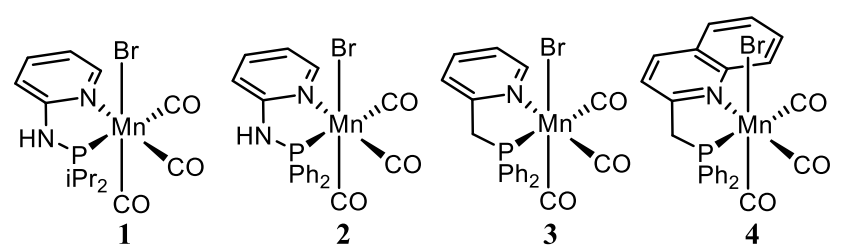

Figure 1. Manganese complexes synthesised for this study.

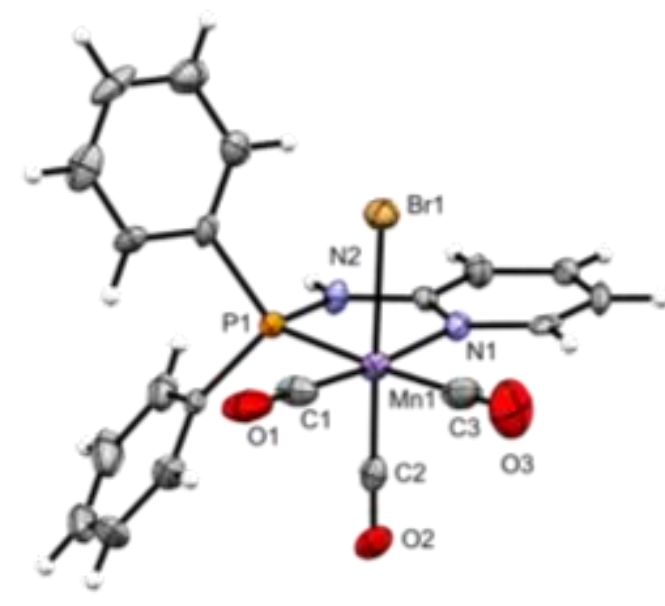

Figure 2. Perspective view of complex 2 with thermal ellipsoids drawn at the $50 \%$ probability level.

Table 1. Optimization of the reaction parameters

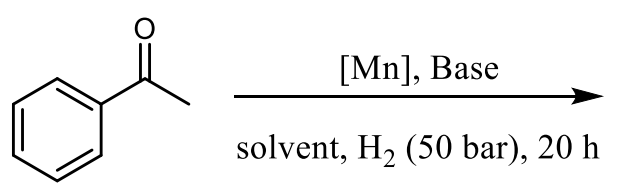

a1<smiles>CC(O)c1ccccc1</smiles>

b1

\begin{tabular}{|c|c|c|c|c|c|}
\hline Entry & $\begin{array}{l}\text { Catalyst } \\
(\mathrm{mol} \%)\end{array}$ & $\begin{array}{l}\text { Base } \\
(\mathrm{mol} \%)\end{array}$ & $\begin{array}{l}\text { Temp. } \\
\left({ }^{\circ} \mathrm{C}\right)\end{array}$ & Solvent & Yield $^{\mathrm{b}}$ \\
\hline 1 & $1(5)$ & $\begin{array}{l}t \mathrm{BuOK} \\
(10)\end{array}$ & 110 & toluene & $>98$ \\
\hline 2 & $\mathbf{1}(1)$ & $t \mathrm{BuOK}(2)$ & 110 & toluene & $>98$ \\
\hline 3 & $1(1)$ & $t \mathrm{BuOK}(2)$ & 80 & toluene & 65 \\
\hline 4 & $2(1)$ & $t \mathrm{BuOK}(2)$ & 80 & toluene & 90 \\
\hline 5 & $3(1)$ & $t \mathrm{BuOK}(2)$ & 80 & toluene & 15 \\
\hline 6 & $4(1)$ & $t \mathrm{BuOK}(2)$ & 80 & toluene & 16 \\
\hline 7 & $2(1)$ & $\begin{array}{l}\text { KHMDS } \\
\text { (2) }\end{array}$ & 80 & toluene & $>98$ \\
\hline 8 & $2(0.5)$ & $\begin{array}{l}\text { KHMDS } \\
\text { (1) }\end{array}$ & 80 & toluene & 81 \\
\hline 9 & $2(0.5)$ & $\begin{array}{l}\text { KHMDS } \\
\text { (1) }\end{array}$ & 80 & $\begin{array}{l}t \text {-amyl } \\
\text { alcohol }\end{array}$ & 76 \\
\hline 10 & $2(0.5)$ & $\begin{array}{l}\text { KHMDS } \\
\text { (2) }\end{array}$ & 80 & toluene & 95 \\
\hline 11 & $2(0.1)$ & $\begin{array}{l}\text { KHMDS } \\
\text { (1) }\end{array}$ & 80 & toluene & 43 \\
\hline 12 & $2(0.5)$ & $\begin{array}{l}\text { KHMDS } \\
\text { (2) }\end{array}$ & 50 & toluene & 93 \\
\hline 13 & $2(0.5)$ & $\begin{array}{l}\text { KHMDS } \\
\text { (2) }\end{array}$ & 50 & $\begin{array}{l}t \text {-amyl } \\
\text { alcohol }\end{array}$ & 51 \\
\hline 14 & $2(0.5)$ & $\begin{array}{l}\text { KHMDS } \\
\text { (2) }\end{array}$ & 30 & toluene & 44 \\
\hline 15 & - & $\begin{array}{l}\text { KHMDS } \\
\text { (2) }\end{array}$ & 50 & toluene & 0 \\
\hline 16 & $2(0.5)$ & - & 50 & toluene & 0 \\
\hline $17^{\mathrm{c}}$ & $2(0.5)$ & KHMDS & 80 & toluene & 93 \\
\hline
\end{tabular}

(2)

a Typical conditions: in an autoclave, $2(0.5 \mathrm{~mol} \%)$, toluene (4 mL), ketone ( $2 \mathrm{mmol})$, KHMDS (2 mol\%), $\mathrm{H}_{2}$ (50 bar) were added in this order. ${ }^{b}$ Yield determined by $\mathrm{GC}$ and ${ }^{1} \mathrm{H}$ 
NMR. ${ }^{c} 300$ equiv. of $\mathrm{Hg}$ (vs 2) were added before $\mathrm{H} 2$ in the reaction mixture.

The catalytic activity of the new complexes $\mathbf{1 - 4}$ was then evaluated for the reduction of ketones under hydrogenation conditions (Table 1). Under the previously optimized reaction conditions determined for the $\mathrm{PN}^{3} \mathrm{P}$ catalyst $\mathbf{I V},{ }^{[6 \mathrm{c}]}$ i.e. complex 1 (5 mol\%), $t \mathrm{BuOK}(10 \mathrm{~mol} \%)$ as the base, toluene, $110^{\circ} \mathrm{C}, \mathrm{H}_{2}(50$ bar), $22 \mathrm{~h}$, a full conversion of acetophenone $\mathbf{a} 1$ to the corresponding alcohol b1 was obtained (entry 1). The catalyst loading could be reduced to $1 \mathrm{~mol} \%$ without any degradation of the activity (Table 1 , entry 2 ). The performance of the four complexes was then compared at $80{ }^{\circ} \mathrm{C}$ (entries 3-6): complex 1 exhibiting the amino-bridged diisopropylphosphino-pyridinyl bidentate ligand $\mathbf{L 1}$ gave a moderate conversion (65\%), whereas the diphenylphosphino derivative 2 gave the alcohol in $90 \%$ yield. Disappointingly, complexes $\mathbf{3}$ and $\mathbf{4}$ featuring the methylene-bridged PN bidentate ligands $\mathbf{L 3}$ and $\mathbf{L} 4$ led to low conversion (15 and $16 \%$ respectively, entries 5 and 6 ). The nature of the base was optimized using $\mathbf{2}$ as pre-catalyst. KHMDS (potassium bis(trimethylsilyl)amide) appeared to be the best one leading to a full conversion with $1 \mathrm{~mol} \%$ of complex and $2 \mathrm{~mol} \%$ of base at $80^{\circ} \mathrm{C}$ in toluene (entry 7 ). With this base, the catalyst loading could be even decreased to $0.5 \mathrm{~mol} \%$ (entries 8-10). With $0.1 \mathrm{~mol} \%$ of catalyst a TON of 430 was achieved (entry 11). The temperature could also be lowered to $50{ }^{\circ} \mathrm{C}$ without significant loss of efficiency (entries 12-13). At $30{ }^{\circ} \mathrm{C}$, however, the conversion dropped to $44 \%$ (entry 14). The influence of the solvent and of the pressure was also evaluated (see ESI, Tables S1 and S2). Notably, tert-amyl alcohol was found to be suitable for this reaction at $80{ }^{\circ} \mathrm{C}$, as an alternative greener solvent (entries 9 and 13). ${ }^{[15]}$ Control experiment showed that the presence of $\mathrm{Hg}$ has no influence on the reaction (entry 17 vs entry 10). Eventually, the optimal condition selected were catalyst $2(0.5 \mathrm{~mol} \%)$, KHMDS (2 mol\%), toluene, 50 bar of hydrogen, 20 h (entry 10).

Next, we explored the substrates scope amenable for the PN manganese precatalyst $\mathbf{2}$ in hydrogenation (Table 2). In general, arylketones bearing both electron withdrawing and electron donating substituents were reduced in very good yields. In the case of halogenated ketones, fluoro- and bromoderivatives (a5, a7) were well tolerated with low catalyst loading, whereas chloro- and iodo-substituted ketones (a6, a8) were not fully reduced, even under slightly forcing conditions. Steric hindrance had a noticeable influence as increasing the length and the branching of the alkyl chains from methyl (a1), ethyl (a13) to isopropyl (a14) induced a significant drop in the conversion (93\% for b1, $97 \%$ for $\mathbf{b 1 3}$ to $35 \%$ for b14). In line with these observations 2', 4',6'trimethylacetophenone $\mathbf{a 1 5}$ was not reduced with this system. Among the various coordinating functional groups, primary amines a12, benzofurane a16, and pyridine a17 were tolerated, but required a higher

catalyst loading. Conversely, cyano-derivatives a10 was reduced in very low yield, and nitro b11 and thiophene b18 moieties completely inhibited the reaction. ${ }^{[16]}$ A series of aliphatic and cyclic ketones was reduced smoothly (b19-b23). Isolated trisubstituted $\mathrm{C}=\mathrm{C}$ double bond in $\mathbf{a 2 3}$ remained completely intact during the hydrogenation process. In order to confirm this selectivity, a series of competitive reduction of acetophenone, in the presence of 1-decene, 5-decene and 5-decyne, respectively, were conducted. In all the cases, the reduction of the ketone proceeds without the reduction of the insaturated $\mathrm{C}-\mathrm{C}$ bond (See Table S3). Finally, para-substituted benzaldehydes (a24-a26) were also reduced to the corresponding benzylic alcohols in high yields showing the tolerance toward ester (b25) and amide (b26) groups.

Table 2. Scope of the hydrogenation of carbonyi derivatives under the catalysis of 2 . $^{\mathrm{a}}$

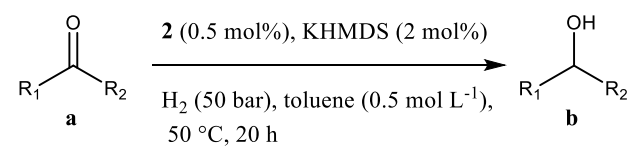

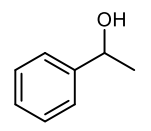

b1 93 (90)

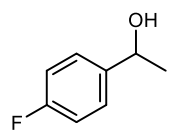

b5 $>98(96)$

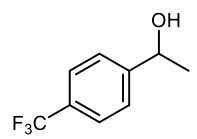

b9 $83(80)^{\mathrm{b}}$

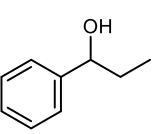

b13 97 (92)<smiles>CC(O)c1ccccn1</smiles>

b17 $96(89)^{\mathrm{d}}$

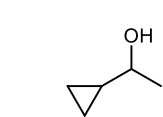

$$
\text { b21 }>98
$$

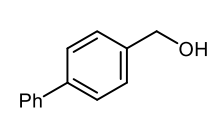

b24 $96(91)^{\mathrm{e}}$

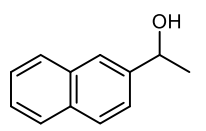

b2 98 (95)

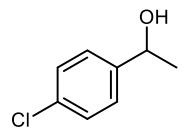

b6 67 (60)

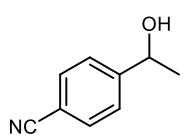

b10 $27^{\mathrm{c}}$

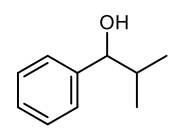

b14 35 (30)

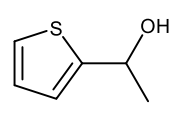

b18 $6^{d}$

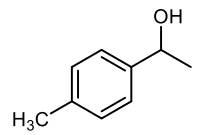

b3 90 (86)

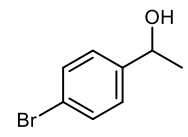

b7 99 (92)

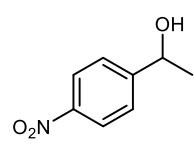

b11 0

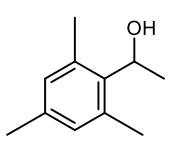

b15 $5^{\mathrm{d}}$

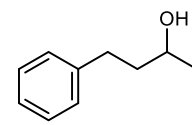

b19 95 (92)

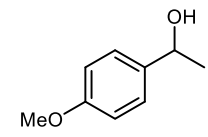

b4 $95(91)^{\mathrm{b}}$

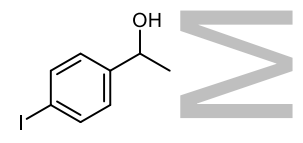

b8 $54(49)^{\mathrm{c}}$

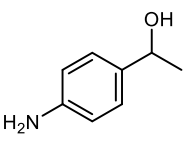

b12 $98(93)^{\mathrm{c}}$

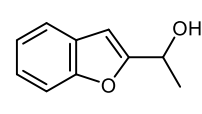

b16 94 (92)

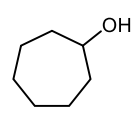

b20 85 (83) 
$50{ }^{\circ} \mathrm{C}, 20 \mathrm{~h}$. Conversion determined by ${ }^{1} \mathrm{H}$ NMR, isolated yield in parentheses. ${ }^{\mathrm{b}} \mathbf{2}(0.5 \mathrm{~mol} \%)$, KHMDS (2 mol\%), $80{ }^{\circ} \mathrm{C} .{ }^{\mathrm{c}} \mathbf{2}(1 \mathrm{~mol} \%), t \mathrm{BuOK}(2 \mathrm{~mol} \%), 80{ }^{\circ} \mathrm{C} .{ }^{\mathrm{d}} \mathbf{2}(5$ $\mathrm{mol} \%), t \mathrm{BuOK}(10 \mathrm{~mol} \%), 80^{\circ} \mathrm{C} .{ }^{\mathrm{e}} \mathbf{2}(1 \mathrm{~mol} \%), t \mathrm{BuOK}(2$ $\mathrm{mol} \%), 50{ }^{\circ} \mathrm{C}$.

In the case of $\alpha, \beta$-unsaturated 4-phenylbut-3-en-2one a27, under the standard conditions, a 13:87 mixture of fully reduced product b19 and ketone a19 was obtained. Interestingly, under milder conditions, at $30{ }^{\circ} \mathrm{C}$, the saturated ketone a29 was obtained selectively, while under hasher ones, at $80{ }^{\circ} \mathrm{C}$, the saturated alcohol b19 was obtained quantitatively (Scheme 2, i and ii). Similarly, chalcone a28 could be reduced selectively to 1,3-diphenylpropan-1-one a29 or to 1,3(diphenylpropan-1-ol b28 (Scheme 2, iii and iv). The reduction of $(R)$-carvone $\mathbf{a 3 0}$, bearing both a conjugated and a non-conjugated $\mathrm{C}=\mathrm{C}$ bond, under mild conditions, led to the formation of a mixture of isomer of dihydrocarvone ${ }^{[17]} \mathbf{a 3 1}$ and $\mathbf{a 3 2}$. Under harsher conditions, dihydrocarveol ${ }^{[18]}$ b30 was obtained in high yield $(87 \%)$. In both cases, the nonconjugated $\mathrm{C}=\mathrm{C}$ bond remained intact. Compared to the reduction of $\alpha, \beta$-unsaturated aldehydes by aliphatic PNP manganese catalysts $\mathbf{I}^{[5 \mathrm{a}]}$ where the unsaturated alcohols were produced selectively, and to the reduction of $\alpha, \beta$-unsaturated esters, ${ }^{[5 b]}$ where solely saturated alcohols were obtained, the present catalytic system allows to reduce exclusively the conjugated $\mathrm{C}=\mathrm{C}$ double bond, supplementing the previously described ones.

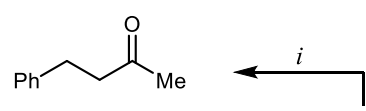

a19 $>98$ (94)

$$
\longrightarrow \begin{aligned}
& \mathbf{a} 27 \mathrm{R}=\mathrm{Me} \\
& \mathbf{a} 28 \mathrm{R}=\mathrm{Ph}
\end{aligned}
$$

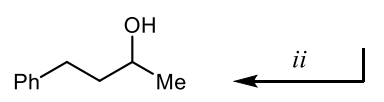

b19 > 98 (92)

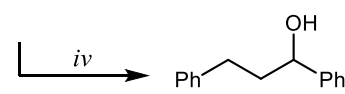

b28 $>98(96)$ i) $2(0.5 \mathrm{~mol} \%)$, KHMDS ( $2 \mathrm{~mol} \%), 30^{\circ} \mathrm{C}, \mathrm{H}_{2}$ (50 bar), toluene, $18 \mathrm{~h}$ ii) $2(5 \mathrm{~mol} \%), t \mathrm{BuOK}(10 \mathrm{~mol} \%), 80^{\circ} \mathrm{C}, \mathrm{H}_{2}$ (50 bar), toluene, $18 \mathrm{~h}$ iii) $2(2 \mathrm{~mol} \%), t \mathrm{BuOK}(5 \mathrm{~mol} \%), 80^{\circ} \mathrm{C}, \mathrm{H}_{2}(50 \mathrm{bar})$, toluene, $18 \mathrm{~h}$ iv) $2(5 \mathrm{~mol} \%), t \mathrm{BuOK}(10 \mathrm{~mol} \%), 100{ }^{\circ} \mathrm{C}, \mathrm{H}_{2}(50 \mathrm{bar})$, toluene, $22 \mathrm{~h}$

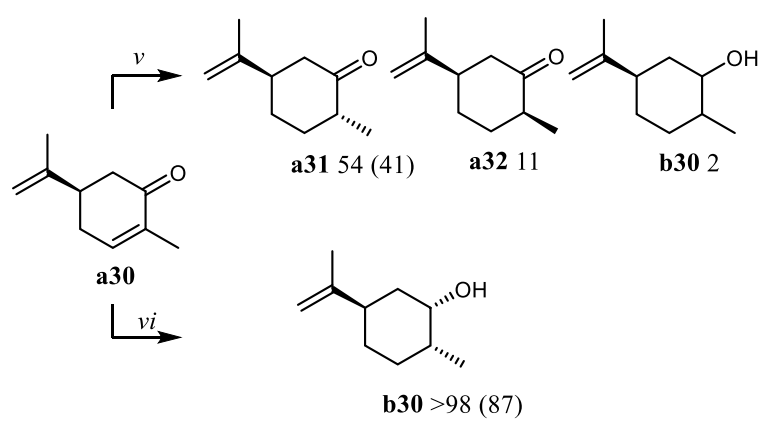

v) $2(1 \mathrm{~mol} \%), t \mathrm{BuOK}(2 \mathrm{~mol} \%), 80^{\circ} \mathrm{C}, \mathrm{H}_{2}$ (50 bar), toluene, $18 \mathrm{~h}$ vi) 2 ( $5 \mathrm{~mol} \%$ ), $t \mathrm{BuOK}(10 \mathrm{~mol} \%), 100^{\circ} \mathrm{C}, \mathrm{H}_{2}$ (50 bar), toluene, $18 \mathrm{~h}$
Scheme 2. Selective reduction of conjugated enones.

In conclusion, a series four $\mathrm{Mn}^{\mathrm{I}}$ complexes bearing readily available phosphino-pyridinyl $\mathrm{PN}$ bidentate ligands have been prepared, fully characterized, and their catalytic activity was evaluated in the hydrogenation of aldehydes and ketones. The complex $\mathrm{Mn}(\mathrm{CO})_{3} \mathrm{Br}\left(\kappa^{2} P, N-\mathrm{Ph}_{2} \mathrm{PN}(\mathrm{H}) \mathrm{Py}\right)(2)$ showed good performances for the hydrogenation of carbonyl derivatives under mild conditions with low catalyst loading and satisfying functional group tolerance, compared to the most active catalytic systems. ${ }^{[6 \mathrm{a}, 6 \mathrm{e}]}$ In terms of catalyst design and taking the $\mathrm{PN}^{3} \mathrm{P} \mathrm{Mn}^{\mathrm{I}}$ complex IV as reference, ${ }^{[6]}$ it appears that simplifying the ancillary tridentate ligand to a bidentate ligand by removing one of its wingtip led to a dramatic increase of the activity of resulting catalytic system. ${ }^{[19]}$ Indeed, the use of the $\mathrm{PN} \mathrm{Mn}^{\mathrm{I}}$ complex 2 allowed reducing the catalyst loading by a factor of ten, and lowering the temperature from $130{ }^{\circ} \mathrm{C}$ to $50{ }^{\circ} \mathrm{C}$, still keeping the same level of activity and chemoselectivity. ${ }^{[6 c]}$

\section{Experimental Section}

General procedure for hydrogenation reactions: in an argon filled glove box, an autoclave was charged with complex $2(5.0 \mathrm{mg}, 0.5 \mathrm{~mol} \%)$ and anhydrous toluene $(4.0$ $\mathrm{mL})$, followed by ketone $(2.0 \mathrm{mmol})$ and potassium bis(trimethylsilyl)amide (KHMDS, $8.0 \mathrm{mg}, 2 \mathrm{~mol} \%$ ), in this order. The autoclave is then charged $\mathrm{H}_{2}(50 \mathrm{bar})$. The mixture was stirred for 20 hours at $50{ }^{\circ} \mathrm{C}$ in an oil bath The crude residue was purified by column chromatography.

For full experimental details for the synthesis of $\mathrm{Mn}$ complexes and for catalytic products, see the Supporting Information.

\section{Acknowledgements}

We thank the Centre National de la Recherche Scientifique (CNRS), the Université de Rennes 1, INCREASE FR-CNRS 3707, the Institut Universitaire de France (IUF) and the Agence National de la Recherche (ANR agency, program JCJC ANR-15 CE07-0001 "Ferracycles").

\section{References}

[1] J. G. De Vries, C. J. Elsevier, The Handbook of Homogeneous Hydrogenation, WILEY-VCH, Weinhem, 2007.

[2] a) S. Gaillard, J.-L. Renaud, ChemSusChem 2008, 1, 505-509; b) R. H. Morris, Chem. Soc. Rev. 2009, 38, 2282-2291; c) R. H. Morris, Acc. Chem. Res. 2015, 48 , 1494-1502; d) L. C. Misal Castro, H. Li, J.-B. Sortais, C. Darcel, Green Chem. 2015, 17, 2283-2303; e) D. S. Mérel, M. L. T. Do, S. Gaillard, P. Dupau, J.-L. Renaud, Coord. Chem. Rev. 2015, 288, 50-68; f) I. Bauer, H.-J. Knölker, Chem. Rev. 2015, 115, 31703387. 
[3] a) R. M. Bullock, Science 2013, 342, 1054-1055; b) W. Zuo, A. J. Lough, Y. F. Li, R. H. Morris, Science 2013, 342, 1080-1083.

[4] a) R. I. Khusnutdinov, A. R. Bayguzina, U. M. Dzhemilev, Russ. J. Org. Chem. 2012, 48, 309-348; b) R. J. Trovitch, Synlett 2014, 25, 1638-1642; c) D. A. Valyaev, G. Lavigne, N. Lugan, Coord. Chem. Rev. 2016, 308, 191-235.

[5] a) S. Elangovan, C. Topf, S. Fischer, H. Jiao, A. Spannenberg, W. Baumann, R. Ludwig, K. Junge, M. Beller, J. Am. Chem. Soc. 2016, 138, 8809-8814; b) S. Elangovan, M. Garbe, H. Jiao, A. Spannenberg, K. Junge, M. Beller, Angew. Chem. Int. Ed. 2016, 55, 15364-15368; c) S. Elangovan, J. Neumann, J.-B. Sortais, K. Junge, C. Darcel, M. Beller, Nat. Commun. 2016, 7, 12641; d) M. Peña - López, P. Piehl, S. Elangovan, H. Neumann, M. Beller, Angew. Chem. Int. Ed. 2016, 55, 14967-14971; e) M. Andérez Fernández, L. K. Vogt, S. Fischer, W. Zhou, H. Jiao, M. Garbe, S. Elangovan, K. Junge, H. Junge, R. Ludwig, M. Beller, Angew. Chem. Int. Ed. 2017, 56, 559-562.

[6] a) F. Kallmeier, T. Irrgang, T. Dietel, R. Kempe, Angew. Chem. Int. Ed. 2016, 55, 11806-11809; b) M. Perez, S. Elangovan, A. Spannenberg, K. Junge, M. Beller, ChemSusChem 2017, 10, 83-86; c) A. BruneauVoisine, D. Wang, T. Roisnel, C. Darcel, J.-B. Sortais, Catal. Commun. 2017, 92, 1-4; d) A. Bruneau-Voisine, D. Wang, V. Dorcet, T. Roisnel, C. Darcel, J.-B. Sortais, Org. Lett. 2017, 19, 3656-3659; e) M. B. Widegren, G. J. Harkness, A. M. Z. Slawin, D. B. Cordes, M. L. Clarke, Angew. Chem. Int. Ed. 2017, 56, 5825-5828; f) F. Bertini, M. Glatz, N. Gorgas, B. Stoger, M. Peruzzini, L. F. Veiros, K. Kirchner, L. Gonsalvi, Chem. Sci. 2017, 8, 5024-5029; g) A. Zirakzadeh, S. R. M. M. de Aguiar, B. Stöger, M. Widhalm, K. Kirchner, ChemCatChem 2017, 9, 17441748; h) N. A. Espinosa-Jalapa, A. Nerush, L. J. W. Shimon, G. Leitus, L. Avram, Y. Ben-David, D. Milstein, Chem. Eur. J. 2017, 23, 5934-5938; i) A. M. Tondreau, J. M. Boncella, Organometallics 2016, 35, 2049-2052; j) A. M. Tondreau, J. M. Boncella, Polyhedron 2016, 116, 96-104; k) A. Dubey, L. Nencini, R. R. Fayzullin, C. Nervi, J. R. Khusnutdinova, ACS Catal. 2017, 7, 3864-3868; 1) V. Papa, J. R. Cabrero-Antonino, E. Alberico, A. Spanneberg, K. Junge, H. Junge, M. Beller, Chem. Sci. 2017, 8, 3576-3585.

[7] a) M. Mastalir, M. Glatz, N. Gorgas, B. Stöger, E. Pittenauer, G. Allmaier, L. F. Veiros, K. Kirchner, Chem. Eur. J. 2016, 22, 12316-12320; b) M. Mastalir, M. Glatz, E. Pittenauer, G. Allmaier, K. Kirchner, J. Am. Chem. Soc. 2016, 138, 15543-15546; c) A. Mukherjee, A. Nerush, G. Leitus, L. J. W. Shimon, Y. Ben David, N. A. Espinosa Jalapa, D. Milstein, J. Am. Chem. Soc. 2016, 138, 4298-4301; d) A. Nerush, M. Vogt, U. Gellrich, G. Leitus, Y. Ben-David, D. Milstein, J. Am. Chem. Soc. 2016, 138, 6985-6997; e) J. Neumann, S. Elangovan, A. Spannenberg, K. Junge, M. Beller, Chem. Eur. J. 2017, 23, 5410-5413; f) A. Bruneau-Voisine, D. Wang, V. Dorcet, T. Roisnel, C.
Darcel, J.-B. Sortais, J. Catal. 2017, 347, 57-62; g) D. H. Nguyen, X. Trivelli, F. Capet, J.-F. Paul, F. Dumeignil, R. M. Gauvin, ACS Catal. 2017, 7, $2022-$ 2032; h) N. Deibl, R. Kempe, Angew. Chem. Int. Ed. 2017, 56, 1663-1666; i) F. Kallmeier, B. Dudziec, T. Irrgang, R. Kempe, Angew. Chem. Int. Ed. 2017, 56, 7261-7265; j) M. Mastalir, E. Pittenauer, G. Allmaier, K. Kirchner, J. Am. Chem. Soc. 2017, 139, 8812-8815; k) J. O. Bauer, S. Chakraborty, D. Milstein, ACS Catal. 2017, 7, 4462-4466; 1) S. Chakraborty, U. Gellrich, Y. Diskin-Posner, G. Leitus, L. Avram, D. Milstein, Angew. Chem. Int. Ed. Engl. 2017, 56, 4229-4233.

[8] a) J. Zheng, S. Chevance, C. Darcel, J.-B. Sortais, Chem. Commun. 2013, 49, 10010-10012; b) J. Zheng, S. Elangovan, D. A. Valyaev, R. Brousses, V. César, J. B. Sortais, C. Darcel, N. Lugan, G. Lavigne, Adv. Synth. Catal. 2014, 356, 1093-1097; c) D. A. Valyaev, D. Wei, S. Elangovan, M. Cavailles, V. Dorcet, J.-B Sortais, C. Darcel, N. Lugan, Organometallics 2016, 35, 4090-4098.

[9] R. van Putten, E. A. Uslamin, M. Garbe, C. Liu, A Gonzalez - de - Castro, M. Lutz, K. Junge, E. J. M. Hensen, M. Beller, L. Lefort, E. A. Pidko, Angew. Chem. Int. Ed. 2017, 56, 7531-7534.

[10] S. M. Aucott, A. M. Z. Slawin, J. D. Woollins, J. Chem. Soc., Dalton Trans. 2000, 2559-2575.

[11] D. Benito-Garagorri, K. Mereiter, K. Kirchner, Collect. Czech. Chem. Commun. 2007, 72, 527-540.

[12] M. Alvarez, N. Lugan, R. Mathieu, J. Chem. Soc., Dalton Trans. 1994, 2755-2760.

[13] E. Mothes, S. Sentets, M. A. Luquin, R. Mathieu, N. Lugan, G. Lavigne, Organometallics 2008, 27, 1193 1206.

[14] CCDC-1565260-1565263 contains the supplementary crystallographic data for this paper. These data can be obtained free of charge from The Cambridge Crystallographic Data Centre via www.ccdc.cam.ac.uk/data_request/cif.

[15] a) R. K. Henderson, C. Jimenez-Gonzalez, D. J. C Constable, S. R. Alston, G. G. A. Inglis, G. Fisher, J. Sherwood, S. P. Binks, A. D. Curzons, Green Chem. 2011, 13, 854-862; b) S. D. Ramgren, L. Hie, Y. Ye, N. K. Garg, Org. Lett. 2013, 15, 3950-3953.

[16] In a competitive experiment, we found that the reduction of acetophenone in the presence of 4nitrotoluene, was completely inhibited (see Supporting Information Table S3).

[17] T. Hirata, A. Matsushima, Y. Sato, T. Iwasaki, H. Nomura, T. Watanabe, S. Toyoda, S. Izumi, J. Mol. Catal. B: Enzym. 2009, 59, 158-162.

[18] X. Chen, X. Gao, Q. Wu, D. Zhu, Tetrahedron: Asymmetry 2012, 23, 734-738.

[19] Mechanistic studies to rationalize the enhancement of activity are under investigations. 


\section{COMMUNICATION}

Hydrogenation of Carbonyl Derivatives Catalysed by Manganese Complexes Bearing Bidentate Pyridinyl-Phosphine Ligands

Adv. Synth. Catal. Year, Volume, Page - Page

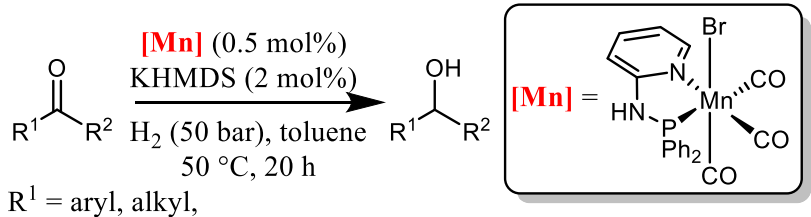

Duo Wei, Antoine Bruneau-Voisine, Téo Chauvin, Vincent Dorcet, Thierry Roisnel, Dmitry A. heteroamoratic $\mathrm{R}^{2}=$ alkyl, $\mathrm{H}$

Valyaev, Noël Lugan and Jean-Baptiste Sortais* 